\title{
Site Preparation Prevents Re-opening of Planting Slits in Heavy-Textured Soils
}

\section{F. W. von Althen}

Department of Fisheries and the Environment, Canadian Forestry Service, Great Lakes Forest Research Centre, Sault Ste. Marie, Ontario
In early spring, when most trees are planted, clay and clay loam soils are generally moist to wet. The planting shoe of conventional planting machines can therefore slice easily through even highly compacted soils. After the tree roots have been inserted in the planting slit, the packing wheels of the machine close the slit tightly and planting appears to have been successful.

However, in late spring or early summer when evapotranspiration begins to draw moisture from the soil, the soil begins to contract and the sides of the planting slit pull apart because their resistance to the force created by soil shrinkage is low. Depending on the texture of the soil and the quantity of moisture withdrawn, a planting slit may open to a width of $5.5 \mathrm{~cm}$ (2.2 in.) and a depth of $15-20 \mathrm{~cm}(6-8 \mathrm{in}$.$) . When this happens, the newly$

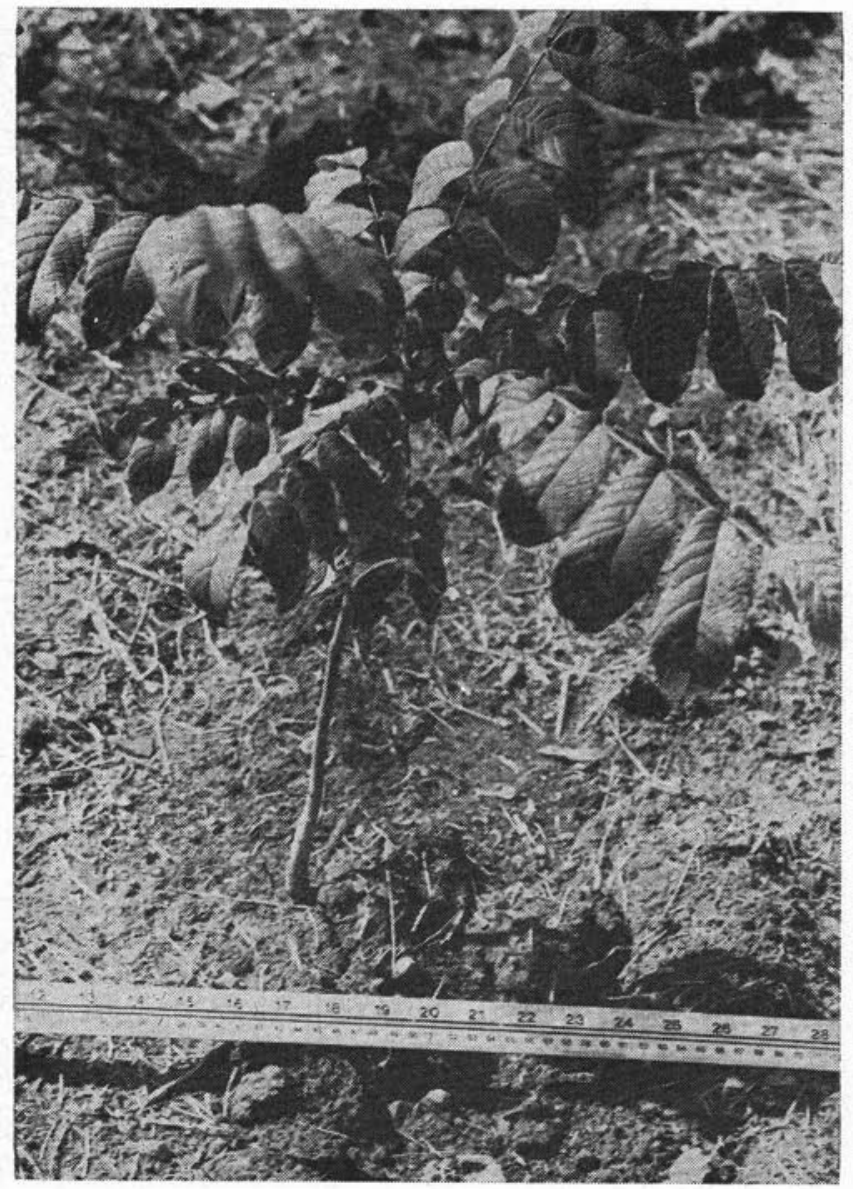

Fig. 1. Tightly closed planting slit on plowed and disked land. planted tree seedlings or transplants lose their support, they start to lean or fall over, their roots dry out, and mice feed on the exposed roots.

During afforestation studies with hardwood seedlings I found that mechanical site preparation eliminated the opening of the planting slit. The studies were carried out in a field near Hornby, Halton County, Ontario. The soil was an imperfectly drained clay loam $46-61 \mathrm{~cm}(18-24$ in.) deep over compact clay. The $\mathrm{pH}$ of the plow layer was 6.4 and the organic matter content was $2.8 \%$. The Ontario Soil Survey (Gillespie et al. 1972) places the soil in the Chinguacousy Series. All trees were planted between May 2 and May 5, 1976, with a light-weight, tractor-drawn Forest View tree planter.

Plowing in July and repeated disking in August

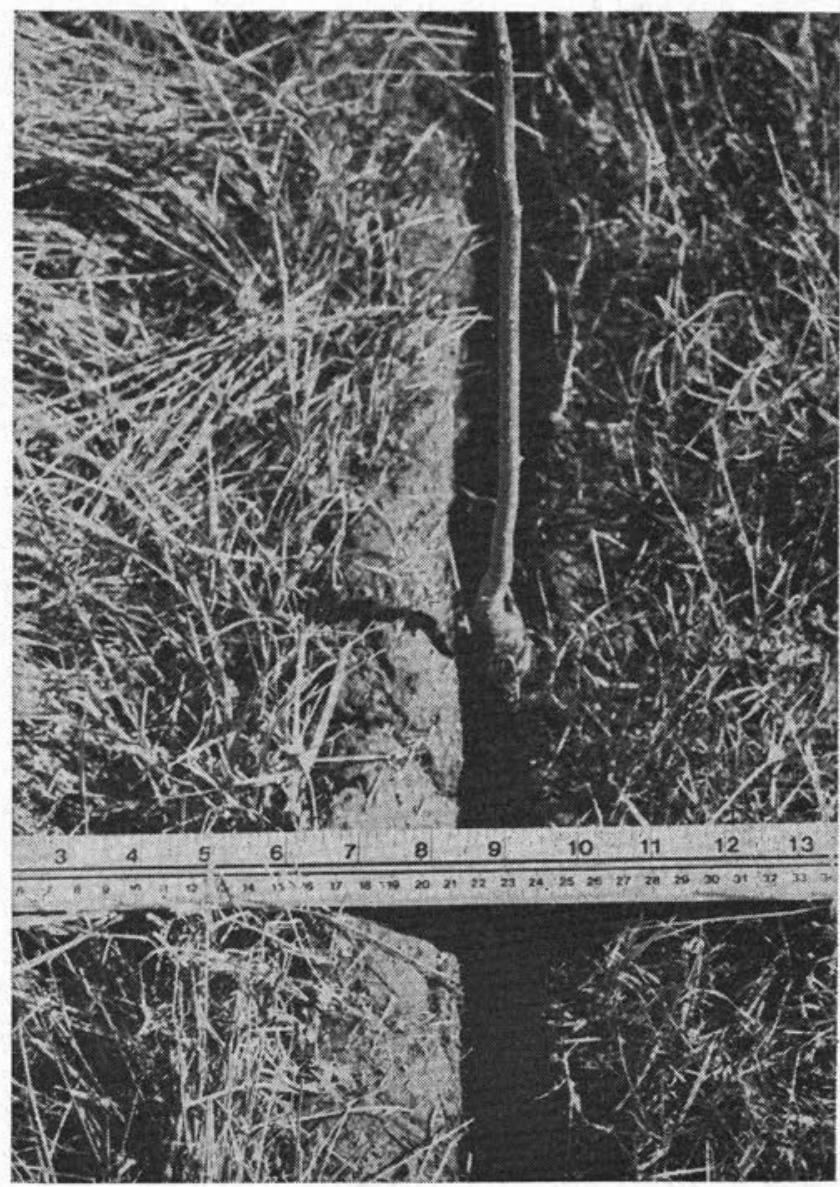

Fig. 2. Open planting slit on land which received no mechanical site preparation. 
and September of the year prior to planting produced an excellent planting bed of crumbly soil which showed no opening of the planting slit at any time (Fig. 1).

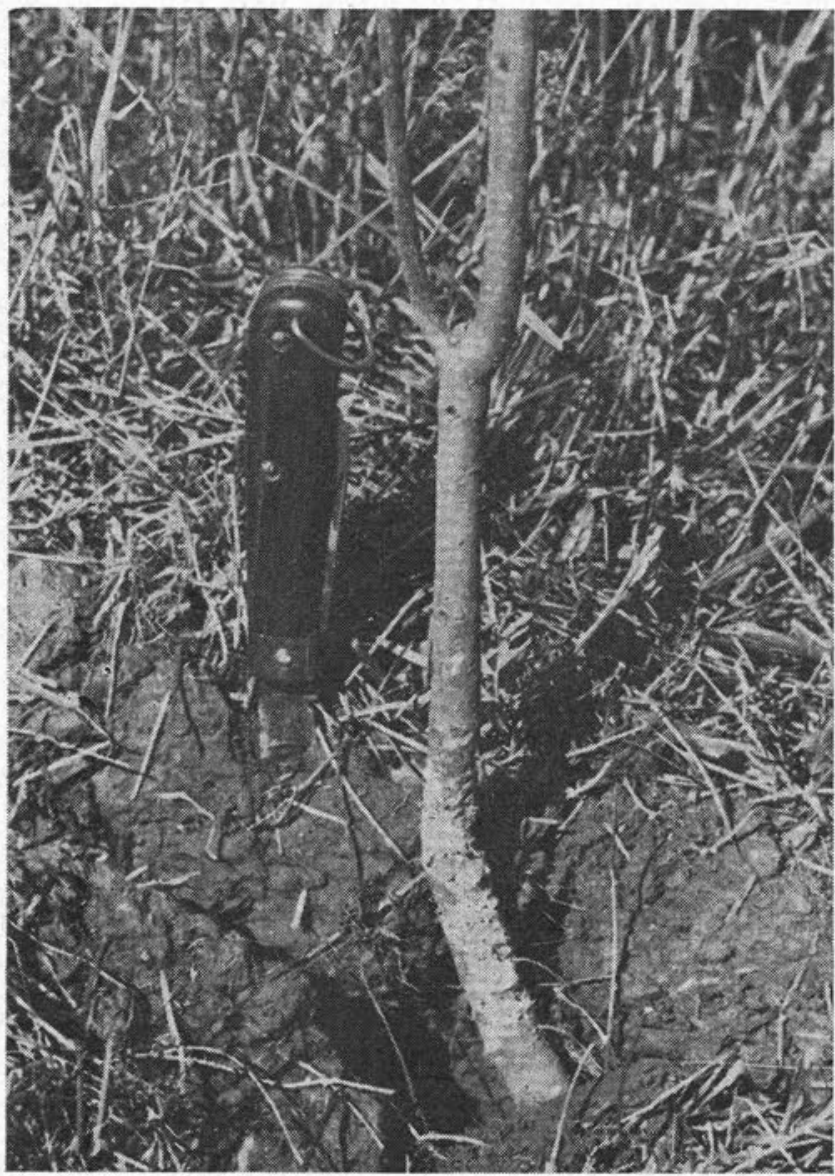

Fig. 3. Partially girdled root of white ash seedling exposed by opening of the planting slit.
Rototilling (four passes with a tractor-drawn rototiller in the autumn prior to planting) also prevented opening of the planting slit.

Plowing and two-pass disking in the same direction were less successful. Short sections of the planting slit opened. These openings were $2-3 \mathrm{~cm}$ (0.8-1.2 in.) wide and $5-8 \mathrm{~cm}(2-3 \mathrm{in}$.) deep; they were generally $30-60 \mathrm{~cm}(1-2 \mathrm{ft})$ long and spaced

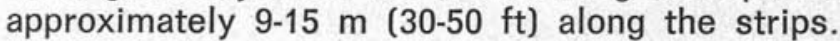

In all areas receiving no mechanical site preparation, the planting slit opened along its entire length. Maximum width of the opening was $5.5 \mathrm{~cm}$ (2.2 in.) and maximum depth was $18 \mathrm{~cm}$ (7 in.) (Fig. 2).

Although $54 \%$ of the trees growing in the open slits survived the first summer, most produced no height growth and $70 \%$ of white ash (Fraxinus americana L.) and silver maple (Acer saccharinum L.) seedlings and $30 \%$ of basswood (Tilia americana L.) seedlings were partially girdled by mice below the root collar (Fig. 3 ).

The width of the slit opening varied slightly during the summer, depending on the moisture present in the soil. However, a slit, once opened, never closed completely through to the last inspection on October 22.

\section{Reference:}

Gillespie, J. E., R. E. Wicklund and M. H. Miller. 1972. The soils of Halton County. Publ. jointly by Ont. Dep. Agric. Food and Can. Dep. Agric. Soil Surv. Rep. No. 43. 

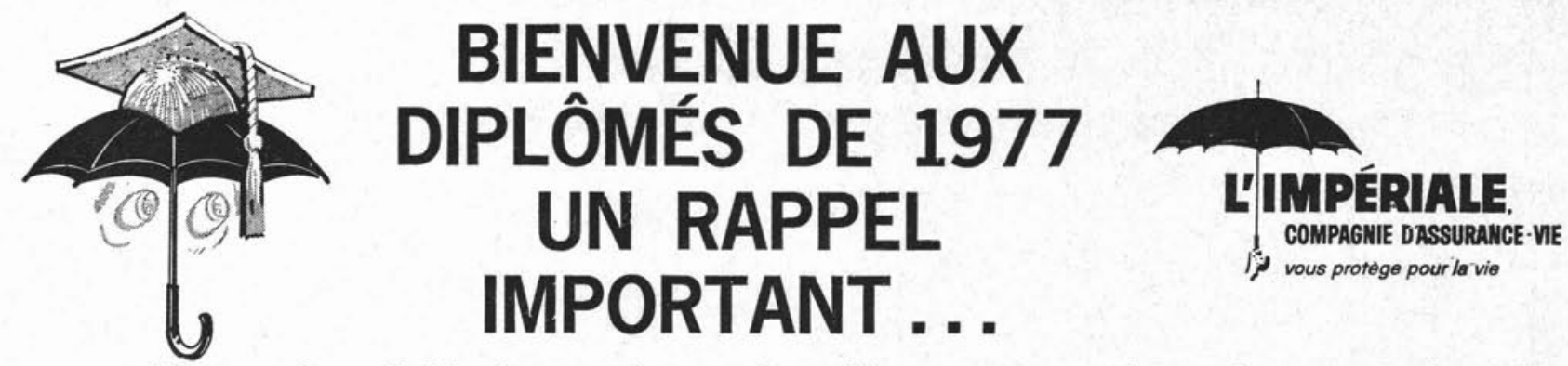

Si vous êtes diplômés en sciences forestières, cette année, ceci peut entraîner des changements importants dans votre vie. Maintenant vous faites face à d'autres responsabilités, telles que la profession que vous avez choisie, le mariage, l'achat d'une maison et la possession d'une assurance-vie.

C'est précisément dans ce domaine que L'Impériale peut vous aider, car elle gère le régime d'assurance-vie de l'Institut Forestier du Canada, en offrant des assurances, à des taux très raisonnables. Par exemple, un montant annuel de $\$ 20.00$ par $\$ 10,000$ d'assurance jusqu'à l'âge de 30 ans. L'assurance est disponible par unité de $\$ 10,000$ pour les membres dont l'âge maximum est de 50 ans, ce qui vous permet d'obtenir un maximum de 10 unités ( $\$ 100,000$ d'assurance) et après l'âge de 50 ans, le nombre d'unités décroît graduellement.

II y a aussi un boni spécial de $50 \%$ payable sur toute réclamation soumise entre le 1er mai 1977 et le 30 avril 1978. Par exemple, si une police de $\$ 100,000$ faisait l'objet d'une réclamation, un montant de $\$ 150,000$ serait payé sans frais supplémentaires. L'assurance-vie de l'IFC est disponible à tous les membres de l'Institut et à leurs conjoints ainsi qu'aux employés à plein temps. Pour obtenir plus de renseignements au sujet de cette assurance précieuse et économique, sans aucun engagement de votre part, adressez vos demandes à I'Institut Forestier du Canada, B.P. 5000, Collège Macdonald, P.Q. HOA 1 CO.

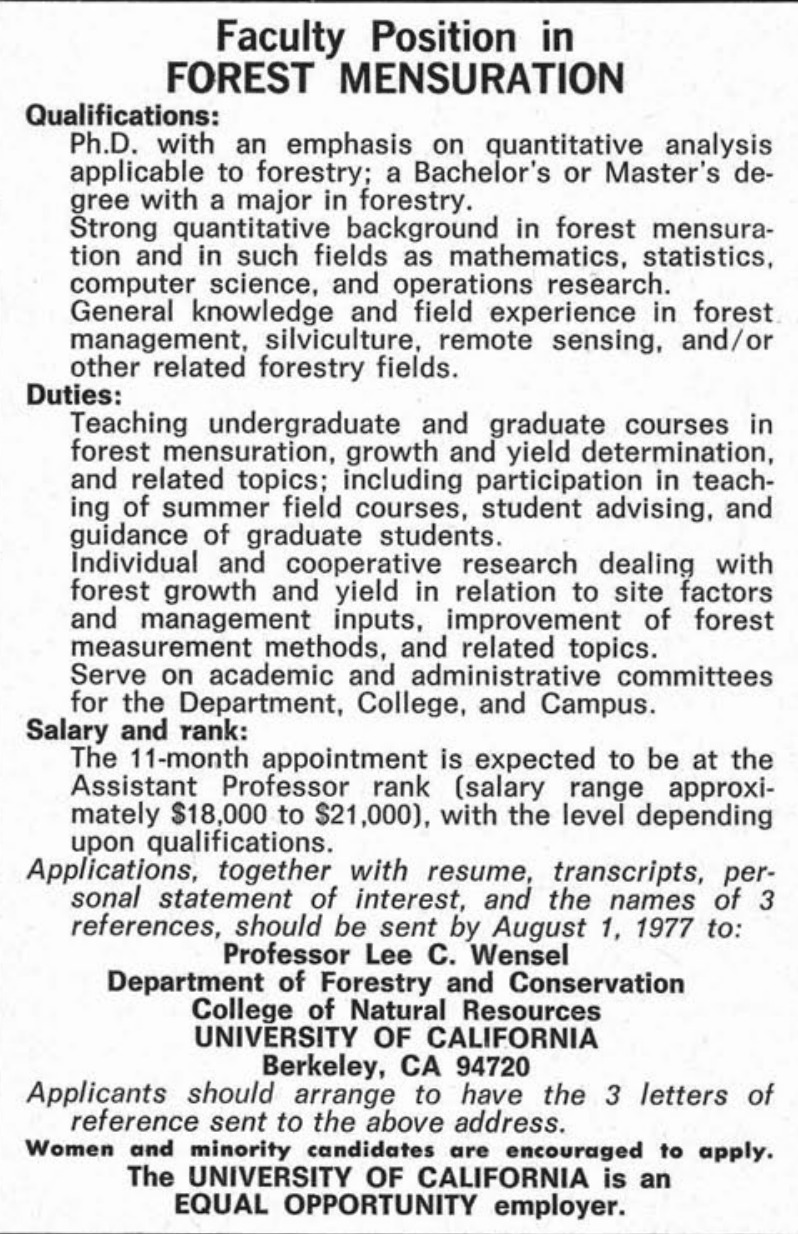

\section{UNIVERSITY OF CALIFORNIA, BERKELEY}

\section{FACULTY POSITION \\ in \\ FOREST OPERATIONS}

Lecturer in Forestry and Research Specialist in Forest Operations. Teaching duties include courses in timber harvesting methods; career counselling; coordination of internships and job placements; supervisor Summer Camp operations and facilities. Research duties include harvesting and related forest management research, liaison with private and public organizations concerned with improved timber harvesting techniques, and supervision of University experimental forests. Candidates should have at least a Masters degree, five or more years of professional or research experience in forestry, qualifications for registration as a professional forester in the State of California, broad knowledge of public and industrial forestry operations, and a strong interest in professional development and career counselling programs. Letters of application including resume, academic transcripts and names of three referees should be sent before August 15, 1977 to:

\section{Professor John Helms \\ Forest Operations Search Committee \\ Department of Forestry and Conservation 145 Mulford Hall \\ UNIVERSITY OF CALIFORNIA Berkeley 94720}

Applicants should request each referee to send a letter of reference directly to the above address.

\section{An Equal Opportunity/Affirmative Action Employer Women and Minorities are Urged to Apply}

